\title{
MICROHISTÓRIA DO TEATRO COLONIAL BRASILEIRO: PADRE ANCHIE- TA E A FESTA DE SÃO LOURENÇO
}

\section{Resumo}

O período colonial brasileiro - visto pela ótica da microhistória - apresenta um cenário multifacetado de povos, línguas e culturas que se somam para produzir o nosso grande Barroco. Os autos de padre Anchieta são analisados, aqui, como produções performáticas que conseguiram, e conseguem até hoje, reproduzir as fronteiras de uma inventiva histórica que, violenta, não deixou de contar com estratégias criativas, artísticas e ousadas. O gênero teatral parece ter sido, nesse momento histórico ímpar, o que melhor conseguiu articular os impasses linguísticos e simbólicos que se estabeleciam entre conquistador e conquistados. A Festa de São Lourenço, de Anchieta, é analisada enquanto manifestação dramatúrgica $e$ literária que bem significa o intuito do colonizador de efetivar o processo de tradução de culturas.

Palavras-chave: microhistória - período colonial - tradução - autos.

\section{Augusto Rodrigues da Silva Junior * Ana Clara Magalhães de Medeiros **} Abstract

The Brazilian colonial period, seen from the perspective of microhistory presents a multifaceted scenario of people, languages and cultures that combine to produce our great Baroque. Anchieta's productions are analyzed here as plays that could - and still can - traduce a historical inventive that was violent, but also creative, artistic and innovative. The theatrical genre seems to have been unique in this historical moment, the genre which could best articulate the symbolic and linguistic impasses that were established between conqueror and conquered. The Feast of San Lorenzo, by Anchieta, is analyzed as a literary and theatrical manifestation that could better make the cultural translation.

Keywords: microhistory - colonial period - plays.

Professor Adjunto do Departamento de Teoria Literária e Literaturas. Universidade de Brasilia (UnB). Brasilia. DF. Brasil. E-mail: augustorodriguesdr@gmail.com

** Graduanda em Letras. Universidade de Brasilia (UnB). Brasília. DF. Brasil. 
O teatro português medieval teve Gil Vicente como seu maior representante. José de Anchieta foi o continuador desse processo na colônia luso-brasileira. Na perspectiva da microhistória, ele foi um dos fundadores, no campo das artes, da literatura e cultura brasileira. Nesse sentido, o caso do jesuíta-dramaturgo presta-se inteiramente à discussão de uma microhistória do teatro nacional.

Partindo de pressupostos bakhtinianos, próximo daquilo que Carlo Ginzburg utilizou em 0 queijo e os vermes (1987) e em outros trabalhos, é possível repensar o período colonial como confronto de diferenças e a imagem de José de Anchieta como o primeiro grande tradutor desse encontro entre cultos e culturas. Este homem, diante da arena detentora de lutas (ainda que violentas) entre colonizadores e colonizados, conseguiu articular dimensões sociais e políticas em seu teatro do sacramento. Verbo constituído de um idioma puramente oral, de corpos vocais nutridos por uma pulsão de linguagem e de uma espetacularidade prática e poética (ZUMTHOR, 2010, pp. 12-16).

Diante do conjunto de vozes a serem compreendidas e respondibilidades europeias que ecoavam no Novo Mundo, entre discursos coletados e estilizados, carregados de condutas, modalidades e inovações, tudo é comungado no instante de seu acontecimento. Nesse caso, pretendemos partir daquilo que Ginzburg define como "registros escritos de produções orais" (1989, p. 203). Trata-se, nesse caso, de retornar aos arquivos coloniais para repensar a elaboração dramatúrgica como o cerne condutor da relação entre literatura oral, representação sacra e de uma performance microhistórica na selva. Utilizando o termo anchietano, universidades da selva, e parafraseando Ginzburg é necessário "aprender a desembaraçar o emaranhado de fios que formam a malha textual destes diálogos" (Idem, p. 09).

Das análises bakhtinianas dos autos e festividades medievais reformulam-se as concepções estéticas e ideológicas que revelam uma capacidade de "[...] desfazer-se de muitas exigências do gosto literário profundamente arraigadas" (BAKHTIN, 2002, p. 03) aos padrões racionalistas e formalistas. As categorias propostas por ele evocam a "multiformidade" e a heterogeneidade, reverberando aspectos corporais, cotidianos, liminares e festivos. Na própria abordagem de Ginzburg, que concentra-se nos protagonistas da cultura popular (1987, p. 21), Bakhtin teria feito uma "abordagem indireta". Aproximando os dois pensadores e articulando esta noção de microhistória do teatro brasileiro, entendemos o trabalho de Anchieta localizado na fronteira entre o literário e a fonte "objetiva" (Idem; Ibidem). Há o elemento inventivo, diferente, em grandes proporções, do romance (rabelaisiano) e abriga ainda o elemento documental que permite mapear o catolicismo carnavalizado colonial (aos moldes de Emanuel Le Roy Ladurie).

Dessa perspectiva, principalmente pelas grandes mudanças no processo de colonização, podemos pensar as primeiras manifestações coloniais luso-brasileiras como expressões dotadas de elementos performáticos e de espetacularidade. Dentro das dimensões do processo de povoamento e de aculturação, as marcas do teatro litúrgico medieval (PICCHIO, 1964, p. 31) serão traçadas nas manifestações teatrais populares e nas variantes católicas que aportaram no Brasil.

Nas atividades dramatúrgicas, encontramos muito da esfera cotidiana e do catolicismo festivo, funcionando sempre como renovação universal e liminar. Algo muito próximo do que descreve Bakhtin no contexto de François Rabelais:

Por seu caráter concreto e sensível e graças a um poderoso elemento de jogo, elas [as festas] estão mais relacionadas às formas artísticas e animadas por imagens, ou seja, às formas do espetáculo teatral. E é verdade que as formas do espetáculo teatral na Idade Média se aproximavam na essência dos carnavais populares, dos quais constituíam-se até certo ponto uma parte. No entanto, o núcleo dessa cultura, isto é, o carnaval, não é de maneira algu- 
ma a forma puramente artística do espetáculo teatral e, de forma geral, não entra no domínio da arte. Ele se situa nas fronteiras entre a arte e a vida. $\mathrm{Na}$ realidade, é a própria vida apresentada com os elementos característicos da representação (BAKHTIN, 2002, p. 6).

Desse ambiente festivo, erige-se um teatro de vícios e moralidades. Trata-se, então, de um ambiente mobilizando as fronteiras entre a arte e a vida. Um processo dialógico da colonização configurado com os topoi lusitano-ocidentais que aportaram na América e que ofereceram o registro dessa expressão liminar, em consonância, por sua vez, com os discursos e revisões (nada paradisíacas) que forjaram padrões estéticos e éticos ligados ao comportamento, à organização social, ao contexto político-religioso. Indo além da experiência objetiva e da fantasia indireta, nos discursos em questão, podemos pensar esse processo como o momento de formação de novos centros da vida política e econômica observados e desenvolvidos, in loco, pelos Jesuítas. Ainda utilizando o pensamento bakhtiniano de Ginzburg, pretendemos analisar o Auto de São Lourenço como um aproximador de ideias e de cotidianos: "É bem mais frutífera a hipótese formulada por Bakhtin de uma influência recíproca entre a cultura das classes subalternas e a cultura dominante" (1987, p. 24). O texto litúrgico-dramatúrgico será entendido como eco e fronteira desses dois universos - escrito e oral (documento).

No Brasil, tivemos espetáculos teatrais e performáticos desde o princípio. Na liturgia católica da primeira missa, carregada de símbolos e dramas sociais, instaura-se um palco em espaço ainda indefinido, desconhecido, a ser dividido e habitado por portugueses e espanhóis. Daí a insistência em denominar fronteiriços esses momentos iniciais de tradução, carregados de sentidos e plenos de metáforas:

Se tudo é teatro no mundo barroco, as igrejas são cenários, as procissões são óperas tristes, as celebrações palacianas são óperas Píricas, enquanto nos campos de batalha desenvolve-se o "teatro da guerra" e o "teatro das operações", e as festas são o exercício apoteótico da carnavalização (SANT'ANNA, 2000, p. 162).

Nesse universo de dominação sociolinguística, o padre-soldado combina a literatura culta clássica com gêneros litúrgicos e festivos medievais. O humanismo renascentista é penetrado por tradições populares ibéricas (PICCHIO, 1964, p. 26-32), presentes nos autos, nas construções líricas de fôlego e na herança retórica, reinventada em sermões. Além disso, a reverberação, no palco dos acontecimentos, convocava novas formas de expressão, completamente reinventadas, dada a necessidade de alcance expressivo, religioso, econômico: Anchieta, por exemplo, utilizou a base teatral do auto de devoção herdada de Gil Vicente aliada à farsa tipicamente renascentista e contrarreformista. A maior prova disso é a utilização do diabo como personagem principal praticamente em todos os seus autos. Mas um personagem imbuído da novidade colonial: diabos indígenas para catequizar índios.

Nesse sentido, o catolicismo lusitano amplifica seu caráter popularesco, imagético e distancia-se do cristianismo puritano castelhano e, muito mais, do anglicano. A dramaturgia de Anchieta lança-se como primeiro movimento em direção a uma pluralidade religiosa, cultural e discursiva que culminará dialogicamente no catolicismo carnavalizado que permeia o imaginário e a prática social brasileira:

No caso luso-brasileiro, a ponte entre a vida simbólica dos tupis e o cristianismo acabou-se fazendo graças ao caráter mais sensível, mais dúctil e mais terrenal do catolicismo português se comparado com o puritanismo inglês 
ou holandês dominante nas colônias da Nova Inglaterra. A devoção popular ibérica não dispensava o recurso às imagens; antes, multiplicava-as (BOSI, 1996, p. 72).

A plasticidade social portuguesa - no esteio do pensamento de Sérgio Buarque de Holanda - funciona como elemento decisivo para a consolidação do processo de colonização por que passamos. Essa chave de entendimento permite pensar nos Autos de Anchieta como reverberações de uma plasticidade religiosa - embora não se perca o caráter dogmático da fé aqui aportada - que foi fundamental dentro da aculturação no colo brasileiro. O caráter "dúctil", flexível, moldável do catolicismo lusitano (FREYRE, 2000) permitiu que os jesuítas - segmento mais intelectualizado e politizado da lgreja - transformassem os catecúmenos em atores, 0 altar em palco, a missa em peça e a pregação em atuação. Se o cristianismo espanhol recusava-se a fundir alteridades para salvar almas, o português não hesitou em multiplicar imagens, como é mostrado em Visão do Paraíso (HOLANDA, 2009). Atrelá-las à simbologia indígena, rearticular a catequese e penetrar no imaginário do outro para converter e conquistar - no esteio do que nos ensinaram os retratistas - foi o maior exercício etnográfico do Jesuíta.

Nesse contexto, a velha Idade Média europeizada reinventa seu universo simbólico em outro solo. Para Ginzburg, na imagem do moleiro friulano, ocorre a "impressionante convergência" de figuras díspares e, nesse encontro, repropomos "com toda força o problema da circularidade da cultura formulado por Bakhtin" (1987, p. 26). Na figura de um jovem e desconhecido padre-enfermeiro, próximo de um dos grupos intelectuais mais significativos no período colonial, é possível reconstituir o movimento das massas distintas e a microhistória de uma personalidade individual. Personalidade que ficou na memória cultural de um país pelas suas mais diversificadas ações, perpetuadas, principalmente, nos seus escritos teatrais - exemplae de seus dramas sociais. Se o confronto entre culturas diferentes reside em uma disposição dialógica, como coloca Ginzburg, pelo fato de um discurso deixar o outro manifestar-se, Anchieta, mesmo de um ponto de vista axiológico fechado, conduz a voz do outro, gerando, com seus espetáculos, essências de um diálogo. Afinal "todo discurso indireto é uma apropriação e uma remodelação por parte daquele que cita" (GINZBURG, 1989, p. 208). Da mesma forma que esta perspectiva permitiu lançar novas luzes aos julgamentos da Inquisição, é possível captar as vozes no teatro anchietano da selva, tão carregado de personagens em conflito, de citações de modelos e transformação dos mesmos. A própria ideia de Paraíso, aliás, teve de ser revisada na conjuntura de uma cristandade emergente.

Nos autos, o pecado e a culpa convivem com a alegria espiritual, o princípio material do culto de um Deus encarnado faz-se verbo nas degradações e profanações do corpo. Podemos, assim, falar em uma intensa vida cultural, pautada pela oralidade, pela comunhão e imposição litúrgica, pelas festas e procissões reinventadas nas selvas e cidades coloniais. $O$ discurso popular, na pena letrada, aproxima literatura e perfomance cultural, revelando unidade no fragmento, sentidos ideológicos de uma sociedade em formação e, assim, ao "ouvir vozes distintas, podemos detectar um choque entre verdades diferentes ou mesmo contraditórias" (Idem; Ibidem).

Se os trovadores medievais entoavam seus versos com guitarras e cantavam romanceiros realizando a implantação de novas línguas na poesia, visto que até o século XI predominavam o grego e o latim, o mesmo fenômeno se deu no Brasil Colônia com a "crônica musical" de Gregório de Matos e as cartas "anônimas" de Tomás António Gonzaga. De caráter festivo e aculturador, o teatro de Anchieta e a sermonística inventiva de Vieira deixaram aportar nestas terras manifestações orais em eventos e rituais litúrgicos performáticos e sérios, mas não menos carnavalizados: 
[...] na experiência brasileira o vocábulo 'público' quase nunca teve acepção política, mas de exibição, em que o 'sair em público', 'ir à rua', ganha forte acepção teatral, carnavalizando-se os atos coletivos (inclusive os religiosos) como forma e consolidação de papéis (ARAÚJO, 1993, p. 26).

Essas manifestações públicas e expressões coletivas, cada qual em seu campo, recriaram expressões e danças, versos e canções, estilos e gêneros. Discursos impressos no grande corpo da multidão:

Sociedade do espetáculo onde as procissões têm estruturalmente componentes da representação alegórica carnavalesca, não estranha que o Brasil esteja entre os países onde os carnavais, procissões e paradas são um composto complexo e que, apesar da diferença entre cada uma dessas manifestações, exibem uma semelhança estrutural, segundo o arguto insight de Roberto da Matta (SANT'ANNA, 2000, p. 175).

O barroco no Brasil passou por um processo de transfiguração cultural, oferecendo leitura ativa do Novo Mundo e dos destinos do homem. Foi instrumento de doutrina e recomposição: - Paraíso revisitado, as visões renovadoras do Éden, o Evangelho repaginado diante de um mundo a ser desvendado - reescrito. $O$ português precisou equacionar a visão edênica que aqui encontrava e a prática catequético-colonizadora urgente, gerando assim: reescrituras. A fantasia do Novo Mundo atrelava-se ao "realismo lusitano" (HOLANDA, 2010) para se constatar que, para viver o Paraíso Terreal, era preciso evangelizar e dominar. O realismo português somava-se à fantasia do novo colo para que se criassem estratégias linguísticas, discursivas e culturais que efetivassem com êxito a colonização.

O resultado disso foi uma profusão de barroquismos multifacetados pelo Brasil: o barroco nordestino metamorfoseou-se. Nas cidades mineiras, da fusão do classicismo árcade e acadêmico, ecoava, pelas paredes dos casarões, a arquitetura católica que oferecia cruzes nos adros e telhados e uma urbanização rococó composta de novos profetas e novas formas de talhar a cultura viva. Nas missões do Sul, a conjunção do guarani-missioneiro esculpiu rostos arredondados e paredes vermelhas em grandes reduções que mais parecem cidades planejadas - e distantes do litoral (LEITE, 1973).

No campo das artes religiosas, produzidas nos primeiros momentos, o catolicismo carnavalizado se dá nos autos-festejo de Anchieta. Mesmo abrigando um processo violento do sujeito católico ao dominar o outro, muito bem estudado por Bosi em Dialética da colonização (1996), é relevante que isso tenha acontecido com a utilização da poesia e do teatro, do sermão e da performance durante as missões, conflitos com índios e europeus, e, principalmente, nos festejos em dias de santo. O clamor do pecado e o sarcasmo impositivo-devocional caminharam juntos sob a aura de um cristianismo prático e econômico:

Ore tupã-ok-etá

i pupé oro-nhe-mbo`ebo,

Tupã r-erobîar-etébo,

t-ekó-pûera mombó pá. 


\section{Nós temos muitas igrejas, \\ dentro delas instruindo, \\ crendo muito em Deus, \\ lançando fora toda maldade}

(ANCHIETA, 1997, p. 114-115).

Nos poemas e nos autos de terreiro, as marcas de oralidade, a fusão de línguas e linguagens englobam voz e corpo:

[...] a nova representação do sagrado assim produzida já não era nem a teologia cristã nem a crença tupi, mas uma terceira esfera simbólica, uma espécie de mitologia paralela que só a situação brasileira tornara possível (BOSI, 1996, p. 65).

Essa terceira vertente simbólica - frise-se: apenas consolidada por características muito específicas da colonização portuguesa, como a coesão social precária, a plasticidade cultural-religiosa e o espírito aventureiro somado ao senso pragmático de realidade - é justamente aquilo que se define como catolicismo carnavalizado no contexto colonial. Nas praças das reduções espanholas e nos terreiros dos vilarejos lusitanos encontravam-se as atividades artísticas, políticas, militares, esportivas, educativas e religiosas.

As fronteiras com códigos eruditos, semieruditos e a criação popular de cenas festivas, a educação formal e religiosa no terreiro e dentro das paredes da lgreja comungam uma transfiguração que ocorria não apenas no campo da linguagem, mas exigia do jesuíta a capacidade de penetrar o imaginário do outro. Para tal, ele utilizava a música, as festas e a imaginária sacra dotada de signos e cores infinitamente marcantes (Idem, p. 25). Os Autos são as manifestações que melhor congregam essa articulação ousada entre o código do letrado colonizador e o código destinado ao povo. A erudição dos nossos primeiros intelectuais se lança à praça improvisada da primeira missa sob o signo da imposição salvífica. Nesse momento singular de tradução, o dogmatismo litúrgico sistemático dá lugar a práticas didáticas alegóricas que usufruem da cultura outra para implantar autoritariamente a sua própria e instaurar assim uma identidade.

Na construção dessa cena catequético-dominadora, iluminam-se estratégias religiosas, históricas e linguísticas: o verbo sagrado e os ecos classistas castelãos (aos moldes do teatro de Gil Vicente) tipicamente portugueses permanecem na transmissão da mensagem, mas as variantes prosódicas e melódicas eram tomadas de empréstimo ao tupi. Língua nova em forma antiga gerando uma expressão adverbial amalgamada de velho mundo no novo paraíso aos olhos do primeiro dramaturgo colonial brasileiro.

José de Anchieta: jesuíta, enfermeiro, homem comum da ordem que alçará os postos/ações de poeta, performer, gramático, tradutor (oral, escrita, cultura), humanista, mestre espiritual, visionário. Dotado de uma capacidade intelectual, é importante notar que ele nascera em ambiente que já ampliava suas fronteiras linguísticas: conhecera a língua basca (do pai); o guanche (língua primitiva da llha de Tenerife - onde nasceu). O castelhano, o português, o latim, o grego e o hebraico, requisitos básicos aos homens da ordem permitiram-lhe que na América lusitana pudesse ampliar esse conhecimento como prática intelectual. No contato com a língua brasílica, variantes dialetais do tupi, tupinambá, tupinambá do norte, dentre outras, ele ampliava o espetáculo do cotidiano no tablado eclesiástico. Outro dado multicultural que explica sua vida e profissão de fé junto aos portugueses e não próximo dos espanhóis é o fato de o Padre-dramaturgo 
vir de uma família de Judeus convertidos, ou seja, era cristão novo, cuja tolerância em Portugal, ao contrário de Espanha, sempre fora maior - marcas daquelas predisposições dialógicas destacadas por Gilberto Freyre.

Anchieta chega ao Brasil com dezenove anos e torna-se Padre apenas com trinta e dois. Nesse percurso, ele, que se tornou refém dos Tamoios aos vinte e um anos (1555) foi ao conflito para trabalhar tão somente como enfermeiro - no confronto com aqueles que apoiavam calvinistas franceses -, acaba dando proteção aos índios. Nesse momento, adquire um aprendizado estratégico para o acordo de paz (e memoriza, durante meses seus poemas eucarísticos bilíngues - citados acima).

Um olhar para a microhistória permite que se perceba como o jesuíta José de Anchieta foi o primeiro dramaturgo do catolicismo colonial brasileiro. O padre conseguiu valer-se de sua ampla formação para fundi-la em um processo de transmissão cultural-cristão que tem seu ápice na criação dos autos. Sua condição de poliglota serviu-lhe para superar as fronteiras linguísticas de contato com os povos tupi e aventurar-se em sermões, peças e poemas escritos em um idioma indefinido, que congregava vestígios de português, castelhano, tupi e tupinambá. Essa indefinição plural do idioma pode ser mapeada nos aspectos corporais e musicais de sua obra e esta microhistória do teatro apresenta-se como uma forma propícia para investigar e indagar os indícios e singularidades de uma época e os dramas sociais de um indivíduo.

A visita microhistórica a dados geralmente esquecidos leva à percepção de que essa era uma preocupação do próprio segmento religioso de que Anchieta fazia parte, a Companhia de Jesus. Grupo já acostumado ao serviço missionário pelo mundo, que atendeu em tão pouco tempo e de forma tão eficiente às necessidades do processo colonizador na América luso-brasileira, prescrevia o aprendizado da língua do dominado como primeiro movimento para a evangelização. A produção artístico-cultural desse período contou, portanto, com a participação decisiva de homens comuns, mas estudiosos, que, portando conhecimentos amplos do saber institucionalizado, souberam manuseá-los minuciosamente para otimizar o contato com a cultura do outro e transformá-la em prática social e discurso indiciário:

Qual é, pois, a sua estratégia, a sua táctica, o seu methodo, o seu systema? ou melhor, como lhes manda doutrinar o seu instituto? Senhores, geralmente falando, o methodo de ensino dos jesuíta é não ter methodo, porque o missionário da Companhia, comtanto que não se desvie da norma geral que the é traçada de - procurar a gloria de Deus e a salvação do próximo, - pode e deve adaptar-se ao meio e á epocha em que vive (Institutum Societatis Jesu. Pragae, anno 1757, v. 1, p. 390-421; v.2l, p. 141. apud NOVAES, 1900).

No âmbito da poética anchietana, a herança trovadoresca mescla-se com a urgência evangelizadora e a expressão vocal-corporal tupi. Se Gil Vicente dá um acabamento dramatúrgico em vários autos, em outros, publicados em livro, há também marcas das encomendas feitas pela nobreza e sua profunda proximidade com as temáticas e eventos católicos ligados a conventos: "não foi mais porque foi pedido muito tarde" (pela nobre Senhora Dona Violante do mosteiro de Oudivelas) (VICENTE, 1942).

Os sermões de Anchieta, por sua vez, mais frágeis, quando comparados com os de Vieira, noticiam, comungam, não alcançam uma amplitude discursiva para o cânone literário, contudo, ampliam-se se entendidos no contexto de uma performance-teatral geral. Sua aparente limitação quantitativa justifica-se pela qualidade e eficácia simbólica da encenação. Essa dramaturgia do Sacramento lida com o princípio maior da performance cultural: o aqui e agora. Vieira, por 
sua vez, compôs seus sermões em um mundo ordenado cujos sacramentos apontavam para o futuro e para a iminente perda a olhos vistos e presentificados. Nesse sentido, a maior contribuição do Jesuíta poliglota ficou conhecida pelo teatro: um reino de anjos e demônios banhado por um "Cristo que ressuscita individualmente e [um] Tupã que destrói em dimensões cósmicas" (BOSI, 1996, p. 67).

Parafraseando Bakhtin, pode-se dizer que o padre utilizava-se do medo cósmico, herança medieval, para infundir no índio a noção de morte e de vida eterna cristãs. Tudo que era sobrenatural e anímico ao índio - o céu, as estrelas, o fogo, a força das águas e os desastres naturais - ilustravam um medo que servia ao poder. Um poder que venceria tudo que fosse maligno e diabólico e que salvaria o convertido dos males post mortem. A aculturação enraizou-se de maneira tão decisiva na cultura por se constituir no Brasil a ponto de o medo cósmico europeu ganhar, aqui, contornos coniventes com a problemática nossa: no tempo da Renascença e da Reforma, houve maciço esforço para "[...] apagar os vestígios animistas ou mediúnicos do comportamento religioso" (BOSI, 1996, p. 69). A perseguição à magia e a caça às bruxas do Velho Mundo transformou-se, em solo brasileiro, na proliferação de personagens diabólicos - abundantes no teatro anchietano - que serviam de alegorias corretivas ao politeísmo anímico, como servia a fogueira no escrutínio europeu.

A tradução de práticas teatrais ocorre com palavras e corporificações. Anchieta organizava narrativas europeias em enredos soltos e voltados completamente para a velha história de um cristianismo revisitado em dimensões díspares: os anjos têm asas de pássaros brasileiros, os demônios são índios de grupos em conflito com os Tupis, e os portugueses, historicamente, têm a noção cronológica abolida (foram salvos antes, serão salvos depois). Noção oportuna, dadas as benesses e lucros do presente na graça de kairós. Na dialógica da tradução cultural, a alegoria é o método de pensamento eleito para a transmissão mais eficaz da mensagem evangélica:

[no] auto anchietano (...) o alegórico é cifra de uma visão legitimista do mesmo poder. Para o teatro do jesuíta valeria antes a afirmação de Lukács: 'A velha alegoria, determinada por uma transcendência religiosa, tinha a missão de humilhar a realidade terrena, contrapondo-a à ultramundana ou celeste, até a sua plena nulidade' (BOSI, 1996, p. 81).

Na perspectiva de Alfredo Bosi, a alegoria é o "discurso do outro" que contém elevado poder de persuasão e alto grau de assimilação. Assim, é pertinente anunciar que a depreensão coletiva e imediata das imagens dos autos jesuíticos fez desse gênero o mais profícuo no processo de aculturação dos primeiros séculos da nossa colonização: uma tradução imagética, corporal e vocalizada.

Os autos compõem-se de partes trabalhadas para gerar o efeito no espectador e, ao mesmo tempo, inseri-lo no todo da festa religiosa e da missa, enquanto um conjunto de performances acontece na mesma lógica discursiva e imagética de uma festa de santo. Note-se, na partitura dramatúrgica abaixo, no Auto de São Lourenço, como se deu esse processo entre cultura popular, procissões nas praças, artes religiosas no terreiro e o papel importante de Anchieta nessa perspectiva microhistórica do teatro de terreiro - teatro da praça missioneira.

A peça foi representada no dia (10 de agosto) de São Lourenço (em 1583 e/ou 1586), onde hoje é a cidade de Niterói. Sua aura religiosa permitiu realizar o ritual litúrgico, louvar a Cristo e aos santos, fazer exercícios de hagiografia e, ainda, levar os índios a atuarem, numa espécie de palco carnavalizado, compactuando com a prática religiosa e levando os outros índios, espectadores, ao acordo inventivo e performático: 
Na Festa de São Lourenço congrega um elenco de personagens tão disparatadas, tão dilatadas no espaço e no tempo, quanto se possa desejar [...] $\mathrm{A}$ unidade dramática é das mais precárias, porém a de ordem pessoal adivinha-se qual seja. O tema de "São Lourenço", com as suas duas conotações, a geográfica e a histórica, a da vila e a do santo, chamou por contiguidade, por associação de ideias, todos os nomes que lhe eram correlatos no pensamento e na vivência de Anchieta, não importando se os fatos ocorreram há vinte ou há muitas centenas de anos (PRADO, 1993, p. 22-23).

A divisão da peça, nessa revisão de gênero microhistórica, oferece dimensão plural para a ideia de auto teatral. Essa dilatação conjuga aquilo que Padre Vieira vai denominar: cristandade - um conjunto de práticas específicas para o novo mundo e para continuidade e benefício dos lusitanos. O espetáculo de Anchieta é o maior exemplo prático da utilização da arte no catolicismo carnavalizado. A lgreja erige suas imagens da condensação da história visando converter o presente. As partes formais e os desdobramentos litúrgicos extrapolam o dramatúrgico e alcançam o campo da performance cultural, do corpo e da voz.

No primeiro ato, a rubrica situa o leitor/espectador, desde o início, no contexto maniqueísta comum à tradição cristã. Demônios e anjos polarizam a cena. Assiste-se à representação performática do martírio de São Lourenço (hagiografia de santos guerreiros, da fundação do cristianismo). Enquanto a expressão corporal acontece, os atores cantam em castelhano um hino a Jesus crucificado e a São Lourenço queimado, que se sacrifica por seu Deus encarnado:

Por Jesus, meu salvador,/ que morre por minhas máculas,/ asso-me nestas grelhas,/ com fogo de seu amor. // Bom Jesus, quando te vejo/ na cruz, por mim chagado,/ eu, por ti, vivo queimado,/mil vezes morrer desejo (ANCHIETA, 1999, p. 3).

Os símbolos agregam múltiplas cargas semânticas: a iminência do fogo, a imagem da cruz, o sangue derramado, tudo em nome do pai. O fogo metafórico do amor de Deus pelos homens presentifica-se na encenação do sacrifício do santo do dia: um grande inquisidor ortônimo reinando no panteão do Filho, dos anjos, dos santos e dos humildes convertidos.

O segundo ato apresenta ações dramáticas intercaladas de prédicas e música religiosa. A presença simbólica de tríades aponta para o principal mistério a ser digerido pelos pagãos: o da trindade santa. No trio diabólico, as figuras maléficas aparecem organizadas em hierarquia católica, que querem destruir a aldeia de São Lourenço: Guaixará (rei dos diabos) e seus servos Aimbirê e Saravaia. Em contrapartida, a trindade celestial é composta por guerreiros incumbidos de defender e salvar os inimigos: São Lourenço (mártir que morreu queimado), São Sebastião (oportunamente flechado) e anjo.

O ato, mais extenso que o primeiro, está assentado em dois focos principais: a condição de pecado assomado ao destino infernal, de um lado; a redenção e salvação eterna, de outro. Desenrola-se com a aclamação do pecado pelos demônios, seguido da vitória do chamado bem, simbolizado pelo anjo e pelos dois santos. Da parte infernal, tem-se uma fala de Aimbirê, muito reveladora: "Por isso o que era teu/ ele agora libertou/ e na morte te venceu". Referindo-se a São Lourenço, que, depois de morto, protege a população, o trecho bem serviria para falar do próprio Cristo, que também "na morte venceu". Mais uma vez, São Lourenço é associado a Cristo, aproximados pela condição de mártires. A diferença é o santo ser seguidor do Deus feito carne e que serve de exemplo do sacrifício por Deus, sina de todo vivente. Salienta-se o papel dos santos na semântica imagética, pois São Lourenço, São Sebastião e vários outros aparece- 
rão nos autos barrocos como mediadores importantes entre os catequizandos e o Deus cristão. Gil Vicente utiliza a mesma estratégia no Auto de S. Martinho, cujo Santo porta uma espada. Valendo-se da importância ritualística que tinham os mortos dentro da tradição tupi, os santos são apresentados como mortos em situação privilegiada de interseção por aqueles que ainda lutam para escapar do fogo eterno propiciado por Aimbirê e seus partidários. A vida eterna e o refrigerium são oferecidos como moeda de aculturação.

O mal, a ser batido, nesse ato, são as práticas culturais indígenas tapuia e tupi: a cauinagem, a dança, os enfeites e pinturas, fumos e feitiços, a antropofagia, a mancebia, a alcovitice e a prostituição (versos 42-58). A obra é uma verdadeira performance, um conjunto de ações e teatralização do conflito entre culturas, em que avulta o medo cósmico dos índios diante dos santos triunfantes que chegam, exemplarmente, a açoitar os índios-diabos. $O$ anjo reafirma 0 que disseram e fizeram os santos com uma prática - parte musical da missa: "Alegrai-vos,/ meus filhos, por minha causa; Eis que aqui estou para vos libertar" (ANCHIETA, 1999, p. 51).

O ato seguinte - terceiro - traz uma encenação hagiográfica e histórica que presentifica as primeiras batalhas do cristianismo em nome de sua afirmação. Mais uma vez Anchieta duplica imagens e utiliza-se de um auto para anunciar a nova Cruzada no Novo Mundo: dois servos demônios, convertidos no ato anterior, torturam Décio e Valeriano, responsáveis pela morte de São Lourenço. A narrativa hagiográfico-histórica conta o suplício dos mártires com imagens que alimentam o medo cósmico e que representam força e sacrifício - inerente a todo cristão, em nome da religião. O dramaturgo e combatente jesuíta vence os romanos não convertidos (no passado presentificado) e os tapuias rebeldes (no presente dramatizado). Nesse ato, uma das mais inventivas criações de Anchieta, Aimbirê (pássaro grande; semelhante ao karaibebé, profeta voador de sua lírica) ajuda os santos contra os combatentes romanos - derrotados historicamente e derrotados novamente com a presentificação dramatúrgica sacra. Notemos que essa atualização das missões como Novas Cruzadas também será ideia corrente em outros discursos jesuíticos, como, por exemplo, no Sermão da Epifania (VIEIRA, OC, vol. I, tomo II, 1959, p. 01 $61[1662])$.

O quarto ato dá lugar a uma nova tríade: o Anjo, o Temor de Deus e o Amor de Deus mandam suas mensagens para os índios (público-alvo de Anchieta): eles devem amar e temer a Deus, que, por eles, tudo sacrificou. Está aí impregnado o principal mandamento da fé cristã: amar a Deus sobre todas as coisas. Mesmo que as narrativas judaico-cristã e suas versões do início não previssem novos mundos, elas assimilam antropofagicamente estes novos povos - que não necessariamente precisariam ser "salvos".

O corpo do santo que morre e se torna sagrado é retalhado (mas não comido) e colocado em uma tumba, como exige o preceito cristão. O medo cósmico ameaça todo aquele que se coloca contra a cruz. Se o segundo e o terceiro ato demonstraram isso por meio de imagens de luta, nesse momento, os "tipos", ao estilo de Gil Vicente, encaminham o diálogo moralista. Cada um traz seu recado: o Anjo trata do martírio, o Temor do (fogo do) inferno, e o Amor da devoção piedosa.

O desfecho, no quinto ato, apresenta um jogral com doze crianças tupi cantando na procissão de São Lourenço. Festa, missa e performance católico-carnavalizada se fundem para a catequese teatral dos índios. Elementos cristãos congregam as práticas locais e atendem questões políticas urgentes: torná-los católicos pelo amor da cruz, pela força do/de trabalho e pela expansão do Império. 
Esse auto, como os demais desse primeiro estágio da colonização, tinham como elenco os próprios indígenas catecúmenos e o palco eram os espaços improvisados na selva ou os átrios das pequenas igrejas. Se do conjunto de alegorias e deformações da liturgia tradicional, utilizadas para fazer a tradução cultural, erige precocemente o nosso catolicismo carnavalizado, não se pode perder de vista que tais manifestações ainda são portadoras da verdade monológica que define a fé dogmática. Nesse sentido, busca-se mostrar que a performance e a dramaturgia coloniais constituem retrato único de um processo de aculturação de mão dupla, em que as reverberações ecoam na nossa cultura até a contemporaneidade. Por mais que tenha pesado a mão do colonizador sobre o nativo, nesse discurso é possível encontrar paradigmas indiciários para a história, como um todo e, principalmente, para a história do teatro brasileiro - sempre entendido a partir do movimento editorial e não exatamente daquilo que é a sua maior força: a voz. Se o autor e os temas são muito estudados, dessa perspectiva microhistórica, aliada à ideia de performance cultural, tem-se uma forma de compreensão pouco frequentada em nossa tradição.

Os contrastes internos da colônia dialogam com o esforço de penetração no imaginário do outro: o colonialismo surge como sistema cultural. Esse Abarebebé (padre santo voador) é o signo do primeiro intelectual atuante (Companhia de Jesus no Brasil) e representa o letrado buscando formas poéticas e teatrais de articular e de manipular os elementos do imaginário ocidental - traduzidos na colônia.

Nos autos de conversão/catequese, Anchieta colocava o discurso cristão na palavra teatral e no corpo do outro. Com isso, uma eficiência religiosa, com certo didatismo autoritário, atendia certo processo de humanização. Na mesma festa, a dramaturgia católico-carnavalizada agrega uma poética oral, elementos anímicos de uma rapsódia e não oferece unidade de ação e de tempo como no teatro clássico greco-romano: as cenas nativas, lutas por território (contra franceses), jogos diabólicos dos Tapuias (a favor dos franceses), louvores, conversão, música, pantomima e diversão integram-se no tempo do auto sério e devotado, católico e carnavalizado.

Nesse universo, que alia procissão e teatralização, as estratégias formais representam um mau selvagem e os pecados, o ethos indígena (identidade, sociedade, cultura) permitindo a Anchieta forjar uma mitologia paralela colonial e uma demonização dos ritos indígenas - isso significa suplantá-los e traduzi-los. Bosi aponta com muita perspicácia para a ressignificação dos rituais mortuários dos índios depois das investidas lusitanas:

[...] os missionários foram percebendo que aquela absoluta ausência de rituais consagrados a Tupã ou a Sumé estava a indicar que se deveria buscar em outro locus simbólico o cerne da religiosidade tupi. O centro vivo, doador de sentido, não se encontrava nem em liturgias a divindades criadoras, nem na lembrança de mitos astrais, mas no culto dos mortos, no conjunto dos bons espíritos e no esconjuro dos maus. Eis a função das cerimônias de canto e dança, das bebedeiras (cauinagens), do fumo inspirado e dos transes que cabia ao pajé presidir (BOSI, 1996, p.69).

A pregação jesuítica direcionava-se, justamente, no sentido de apagar o caráter anímico e pagão dessas celebrações e reconfigurá-las para que se padronizassem à doutrina cristã em outro locus simbólico: a cena teatral. Nesse sentido, mesmo que de forma limitada, pode-se dizer que dessa revisão microhistórica de José de Anchieta é possível apreender um campo específico de crenças anímicas em confronto com crenças populares europeias. Nesse campo, aparentemente uniforme do catolicismo, ecoa um discurso ampliado pelo catolicismo carnavalizado colonial que permite reconhecer habitus locais e aproximações entre técnicas e culturas 
diferentes. Além disso, pretendemos mostrar como essas transformações sofridas ao longo de séculos podem ser apreendidas nos textos literário-teatrais que ficaram para a posteridade impulsionadas pelo contato dos índios com os missionários.

Assim, os primeiros colonizadores/tradutores conseguiram apresentar no palco a fé no Deus uno para um povo que sequer possuía algo que considerasse como divindade criadora de tudo e de todos, mas uma relação anímica dinâmica e mais respeitosa para com o seu diferente. Além de suplantar-lhes as celebrações espirituais para transformá-las em venerações aos mortos católicos, os santos, ainda no esteio do pensamento de Ginzburg (amparado por Bakhtin), podemos dizer que o processo colonial propiciou uma aculturação simbólica predominantemente monológica, de cima para baixo, mas podemos dizer também que o gênero teatral permitiu o estabelecimento de índices e de aproximações dialógicas que permitem, ainda hoje, a comparação entre culturas, crenças e modos de ver e habitar o Paraíso Terreal.

Essas tensões de culturas e sentidos múltiplos aparecem no jogo teatral desenvolvido por Anchieta, jogo que se constitui como verdadeiro símbolo do equacionamento - de objetivos políticos e religiosos - que poderia ter sido improvável se não tivesse contado com as soluções incontestavelmente violentas, mas também ousadas, criativas e artísticas dos intelectuais que aqui primeiro aportaram.

Diante desse conjunto de detalhes, parece mais viável designar a obra de Anchieta como uma performance teatral híbrida que articula uma pluralidade de gêneros entre dramas, campos e metáforas, todos diluídos em um objetivo maior, que é a festa de louvor em honra de anjos, santos e um Deus encarnado, crucificado e individualizado (economicamente) pelo processo colonizador.

\section{Referências}

ANCHIETA, José de. Teatro. São Paulo: Martins Fontes, 1999.

. Lírica Portuguesa e Tupi. São Paulo: Martins Fontes, 1997.

ARAÚJO, Emanuel. O teatro dos vícios - transgressão e transigência na sociedade urbana colonial. Rio de Janeiro: José Olympio, 2008.

BAKHTIN, Mikhail. Cultura popular na Idade Média e no Renascimento - o contexto de François Rabelais. São Paulo: Annablume/Hucitec, 2002.

BOSI, Alfredo. Dialética da colonização. 3. ed. São Paulo: Companhia das Letras, 1996.

FREYRE, Gilberto. Casa-grande \& Senzala. Rio de Janeiro; São Paulo: Record, 2000.

GINZBURG, Carlo. O queijo e os vermes: o cotidiano e as ideias de um moleiro perseguido pela inquisição. São Paulo: Companhia das Letras, 1987.

. Ensaios de micro-história e outros ensaios. Rio de Janeiro: DIFEL, 1989.

HOLANDA, Sérgio Buarque de. Raízes do Brasil. 26. ed. São Paulo: Companhia das Letras, 2009.

.Visão do paraíso. 6. ed. São Paulo: Companhia das Letras, 2010.

LE ROY LADURIE, Emmanuel. O carnaval de romans: da Candelária à quarta-feira de cin- 
zas, 1579-1580. São Paulo: Cia das Letras, 2002.

LEITE, Bazilisso. Generalidades das missões jesuíticas. Porto Alegre: Editora A4, 1973.

NOVAES, Américo de.; et al. III Centenário do venerável Joseph de Anchieta. Paris; Lisboa: Aillaud, 1900.

PRADO, Décio de Almeida. Teatro de Anchieta a Alencar. São Paulo: Perspectiva, 1993.

PICCHIO, Luciana S. História do Teatro Português. Lisboa: Portugalia, 1964.

TURNER, Victor. Dramas, campos e metáforas: ação simbólica na sociedade humana. Niterói: Eduff, 2008.

SANT'ANNA. Affonso Romano de. Barroco: do quadrado à elipse. São Paulo: Rocco, 2000.

VICENTE, Gil. Obras completas. Lisboa: Livraria Sá da Cosła, 1942. v. 2 [Obras de devoção].

VIEIRA, António. Sermões. In: Obra Completa. Porto: Lello \& Irmão, 1959, v. 1, tomos I e II.

ZUMTHOR, Paul. A letra e a voz: a "literatura medieval". São Paulo: Companhia das Letras, 2001. . Introdução à poesia oral. Belo Horizonte: Editora UFMG, 2010. 